\title{
DEVELOPMENT AND APPLICATION OF CONCEPTUAL AND \\ ANALYTIC FRAMEWORKS FOR COMMUNITY ENGAGEMENT AT \\ A SOUTH AFRICAN HIGHER EDUCATION INSTITUTION
}

\author{
E. M. Nkoana* \\ e-mail: nkoanem@unisa.ac.za
}

\author{
M. M. Dichaba* \\ e-mail: dichamm@unisa.ac.za
}

*Department of ABET and Youth Development

University of South Africa

Pretoria, South Africa

\section{ABSTRACT}

University-community engagement is gaining momentum as the latest core business of South African universities in addition to teaching and learning. However, the lack of conceptual and analytic frameworks to assess the progress towards realising university-community engagement will eventually invite criticism that might harm genuine university-community relations. This article uses a systematic literature review approach to develop conceptual and analytic frameworks that are later applied to critically assess the university-community engagement of a leading South African university. Results show that the poor conceptualisation of university-community engagement affects its operationalisation leading to dominant 'weak' as opposed to 'strong' university-community engagement initiatives. Last, the environmental management field offers great opportunities for genuine UCE with community members.

Keywords: analytic framework, conceptual framework, critical assessment, South African Higher Education Institutions, University-Community engagement

\section{INTRODUCTION}

University-Community Engagement (UCE) has increasingly become a core business of South African universities over the past decades. UCE is needed to contribute solutions to domestic triple challenges of inequality, poverty, and unemployment but also realising global commitment such as environmental protection. Addressing these wicked problems that include climate change, crime, desertification, inequality, and unemployment and so forth requires the involvement of diverse actors-including community members. There has not been a formal framework or typology to guide the involvement of community members in UCE endeavours up until now. 
This article presents the process followed in the development and application of a formal framework that will guide the involvement of community members in UCE efforts in South Africa and elsewhere. To achieve this, our article begins by conceptualising the highly contested nature of the terms 'community' and 'engagement'. This conceptualisation is then used to operationalise UCE by delineating the normativity, procedural, and empowerment principles. These principles are then applied to guide the development of a formal frameworkin the form of a UCE typology. The typology is then applied to critically assess UCE programmes and projects of a leading South African university.

An overview of the results shows that weak UCE dominates the strong UCE initiatives. Weak UCE endeavours include activities organised around community services and community outreach projects. Strong UCE efforts are predominantly located in the fields of environmental management including agriculture and renewable energy. This might not come as a surprise since a large section of South African society still subsists on agrarian activities in remote rural areas that are not connected to the national electricity grid-making those communities fertile ground for technological experimentation by universities.

\section{METHODOLOGY}

\section{Section 1: Conceptual and analytic frameworks for UCE}

This is a qualitative desktop study utilising systematic literature review (Kitchenham 2004; Kitchenham et al. 2009) and secondary data analysis methodologies (Onwuegbuzie, Leech and Collins 2012). A Boolean search was conducted on Google Scholar search engine that led to journals in popular journal databses incuding: Ebsco Host, Emerald Insight, Science Direct, Sage Publications and South African Electronic Publications (SA ePublications). These various journal databases were considered in order to limit the various 'search results' biases such the North American bias (Ebsco Host), European bias (Emerald Insight and Science Direct), and the South African bias (SA ePublications). The following key search words were used in the Boolean search: 'Community Engagement', 'Community Engagement AND Higher Education', ‘Community Engagement AND Higher Education AND Universities', 'Community Engagement AND South African Universities', and 'Community Engagement AND South African Higher Education Institutions'. A backward snowballing approach was used to identify peer-reviewed scholarly articles by searching the reference sections of leading articles. We excluded academic books, dissertations, conference proceedings, and grey literature sources such as official reports and scholarly work that is not published in English. 


\section{Section 2: Application of the conceptual and analytic frameworks to critically assess UCE at a South African university}

The authors will use a systematic literature review technique and develop conceptual and analytic framework and subsequently apply them to critically assess UCE dimension of the University of South Africa (Unisa). Unisa's UCE endeavours shall be critically assessed along a gradual continuum (typology) that is constituted by three categories namely: Community Services, Community Outreach, and Community Engagement (in Table 1). The authors' categorise Community Services and Community Outreach as Weak UCE and Community Engagement as Strong UCE (this categorisation is explained later in the discussion section). Secondary data on UCE projects was obtained from the various colleges at Unisa. These projects were analysed using the newly developed assessment typology (see Table 2 for results). The links to the websites of considered colleges and their various community engagement projects can be found in Appendix 1.

\section{Case study description}

Unisa is used as an instrumental case study in order to test and refine the newly developed UCE frameworks and typology (Baxter and Jack 2008). Unisa was founded in 1873 as the University of the Cape of Good Hope and later became the first public university in the world to teach exclusively by means of distance education in 1946. Unisa is unique in that it was the only university in South Africa to provide all people with access to education, irrespective of race, colour or creed during the apartheid era. Today, Unisa is the largest open distance learning institution in Africa and the longest standing dedicated distance education university in the world. Unisa enrols nearly one-third of all South African students. It offers short courses and certificate programmes to three-and four-year degrees and diplomas, to over 400000 registered students. This institution actively promotes community engagement alongside teaching and research activities. The Department of Community Engagement and Outreach drives Unisa's UCE endeavours. There are five main categories of UCE at Unisa and these are: Curriculumrelated community engagement, Non-curriculum-related community engagement, Researchrelated community engagement, Community building and capacity building, and Community outreach. Unisa is headquarters in Pretoria, the capital city of South Africa and it also has campuses in throughout the country and in Ethiopia. 


\section{CONCEPTUAL FRAMEWORK}

\section{Operationalising community and engagement in the context of UCE}

\section{Contested nature of community}

Around 94 definitions of the term 'community' exist in literature indicating its highly contested nature (Banks 2003). We synthesis and categorise these definitions into four broad categories namely: descriptive communities, territorial communities, communities of interest or identity communities, normative communities, and active communities. Descriptive communities refer to the social scientists' use of the term to describe a group or network of people, institutions, or organisations that share 'something' in common. This generally involves both (social) interaction within the group or network, and a sense of attachment, identification with or belonging to. Territorial communities, like the name suggests, share a geographical location such as town, city, township, and/or a village. Communities of interest or identity are based on characteristics other than physical proximity such as ethnicity (Asian), professional membership (Educators’ association, Engineers' association), and religion (Judaism, Hindu) and so forth. Normative communities or community as values refers to the universal values that are associated with communities. These universal values may include, but are not limited to, affection, friendliness, care, dignity, respect, and love and so forth. In scientific literature, Butcher et al. (1993) identifies three 'community values' as: solidarity, participation, and coherence. We add the African value of Ubuntu (Green and Mercer 2001).

Banks (2003) warns us that these categories of community are not mutually exclusive, as some communities, such as mining or fishing villages, for example, may be rooted in both shared locality (near mines or fishing water ways) and common economic interest (as miners and fishers). In this regard, this author posits that it is important to note that the term is very often used in the context of policy and practice simply to refer to a geographical neighbourhood (for example, 'the Cape Town community'), or set of individuals who may not actually feel any sense of attachment to an area or identity with any group referred to. Strictly speaking, this is a misuse of the term, but it is used so commonly that we need to take it into account. The term 'community' is often used in a policy context to mean simply people who live in an area and/or uneducated people-that is, people who are not professional (Banks 2003). This is often what is meant when reference is made to 'community leaders', 'community stakeholders', 'consulting the community', or even UCE. This use of the term may imply a sense of belonging or attachment, even though there is none whatsoever. 
We adopt the meaning of an Active community in this article. This type of community builds on and encompasses the descriptive, territorial, identity, and value (normative community) meanings identified above. It refers to collective action by members of territorial or interest communities that embraces one or more of the communitarian (Etzioni 1995a; 1995b) values of coherence, participation, solidarity (Green and Mercer 2001) and Ubuntu (Nkoana and Dichaba 2016). This is the idea of community that decision makers often have in mind when they seek to promote initiatives drawing upon community strengths and capacities (Banks 2003). In the context of this article, we utilise the concept to active communities to refer to external stakeholders that collaborate with university staff members in university-community engagement endeavours. The use of the term 'active' also implies that external stakeholders are not mere spectators and passive recipients of 'benefits' from universities but are actively involved and work alongside university staff members in university-community engagement efforts-as we shall see later.

\section{Characterising engagement}

Engagement is an act in which two or more partners, such as people, organisations, and/ or nations, enter into an asymbiotic agreement (i.e. development cooperation agreement) or mutual destruction (such as in armed conflicts). The essence of engagement is that both parties actively participate. However, literature, notably Arnstein Ladder of Participation (Arnstein 1969) has demonstrated that participation can occur at different levels and it increases as the ladder progresses to higher rings. Arnstein's Ladder of Participation (in Figure 1) shows that participation begins with involvement, or non-participation, characterised by manipulation and therapy through to citizens control. Participation increases as we move higher through the ladder from manipulation up until the citizens are empowered to take ownership of their lives or total control of any initiative (i.e. Citizen Control).

According to Arnstein (1969) manipulation refers to non-participation by powerless people that are coerced by powerful stakeholders to achieve their own ends (Cornwall 2008). Therapy aims to cure or educate the participants and their role is only to achieve public support through public relations rather than contributing to any decision making process. Informing or communication is vital for legitimate participation, but all too frequently the emphasis is on a one-way flow of information, as there is no feedback mechanism (Cornwall 2008). Consultation is also a legitimate step in utilising apparatus such as attitude surveys, neighbourhood meetings, and public enquiries (Cornwall 2008). However, Arnstein (1969) argues that this is just a window dressing exercise. Co-option is a typical practice in placation wherein citizens are 


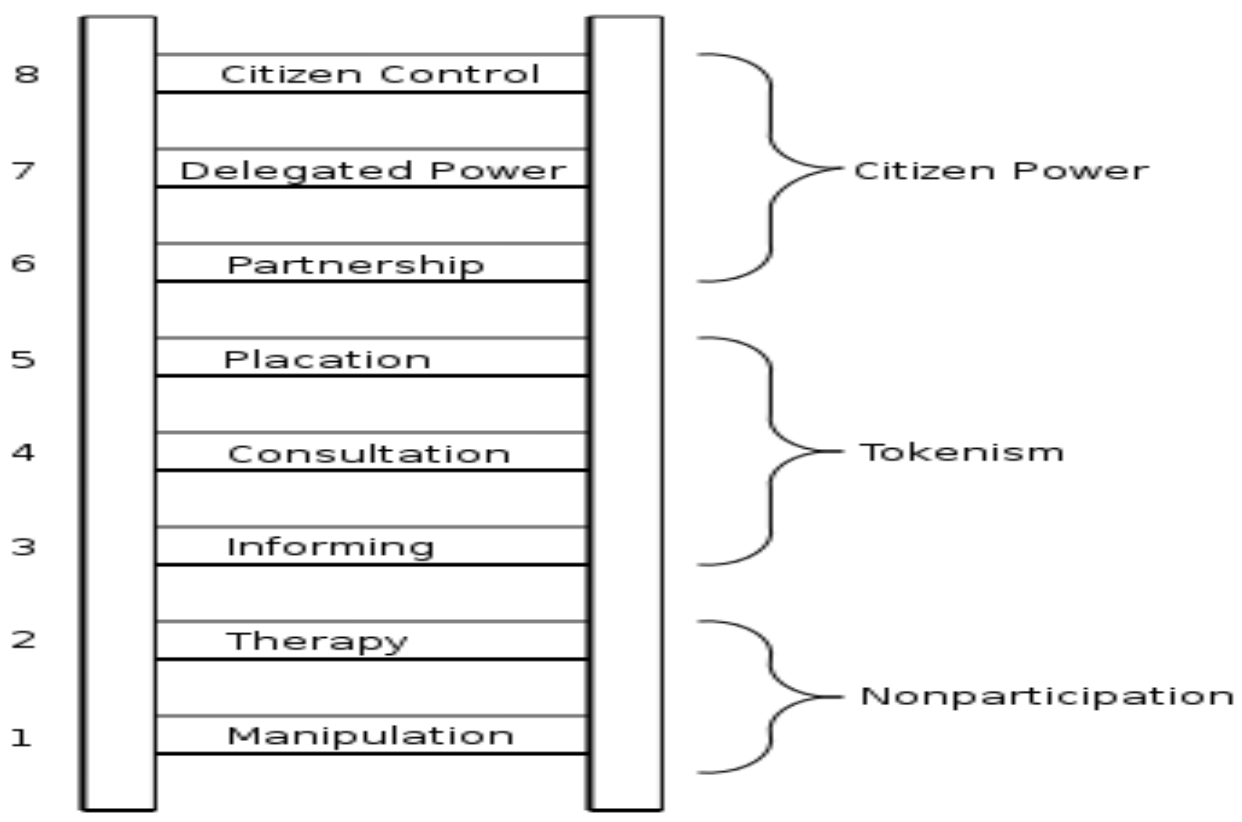

Figure 1: Arnstein's Ladder of Participation (1969)

invited to play an advisory role or to plan, but power holders and/or gatekeepers retain the right to judge the legitimacy or feasibility of the advice. In partnership, power is redistributed through negotiation between community members and decision makers (Cornwall 2008). Planning and decision-making responsibilities are shared. The poor and powerless citizens can negotiate and engage in trade-offs with power holders, for example, through joint committees. In Delegated power, Arnstein (1969) considers that at this level, citizens hold a clear majority of seats on committees and have delegated powers to make decisions (Cornwall 2008). The public thus now has the power to assure accountability of the policies and programs for themselves. Last, in Citizen Control the residents handle the entire process of planning, policymaking, and managing a programme, for example, neighbourhood cooperation, with no intermediaries between it (Cornwall 2008). Furthermore, citizens formerly without power obtain the majority of decision-making seats in the committees or full managerial power (Arnstein 1969). Most of Arnstein's Ladder is characterised by non-participation and limited participation akin to manipulation and tokenism. We begin to see genuine UCE creeping into the ladder through partnership, delegated power, and citizens' control. This is because, in genuine UCE, information and decision-making flows into both directions from the academics to the community members and vice versa-this is what UCE is supposed to be.

\section{Operationalising the concepts of community and engagement further by delineating the principles of UCE}

We can derive the guiding principles of UCE from the above conceptualisation of community 
and engagement. Guided by this conceptualisation, we present the normativity, procedural, and empowerment principles of UCE in a South African context.

\section{Normativity principle of UCE}

Universities across the world pride themselves as guardians and champions of societal values such as equality, equity, human rights, and (social) justice a (Bernardo et al. 2012) and Ubuntu. Societal values are abstract ideals which evoke emotional reactions and are typically expressed in terms of good or bad, better or worse, desirability or avoidance. They define and/or direct us to goals, frame our attitudes and views, and provide a yardstick against which human behaviour can be judged (Waas et al. 2011, 1646). At the institutional level, the normativity principle can be applied as a useful tool to interpret the organisational culture or institutional values (i.e. founding values that are secular or religious) of universities expressed in their UCE vision and mission statements, and policies. Ideally, such statements and policies should guide universitystakeholder relationships that espouse the humane treatment of external stakeholders' particularly powerless members of active communities. This principle argues that such utopian ideals should be built into UCE vision and mission statements and policies. Perhaps by asking following questions: Is UCE empowering or exploitative to the active communities and/or external stakeholders with which universities work? Do university staff members understand their roles and responsibilities as moral champions of university values? Let us use Bernardo et al.'s (2012) case study to shed light into how founding values can affect UCE policy and practice at the institutional levels. Bernardo, Butcher and Howard (2012) compare UCE at both the supranational (i.e. country) and institutional (i.e. university) levels between an Australian and a Philippine university. Both universities were founded by Catholic missionaries albeit they exists in different economic (developed and developing country), socio-cultural (religious versus secular country), and political contexts. These diverse contexts have shaped UCE in these institutions differently, with the Australian university pursuing a Mission-Based Model to UCE, and the Philippine university responding to the basic needs of its surrounding community through a Needs-Based Model-because of the high poverty levels in that country. Catholic religious values on which these two universities were founded continue to influence their organisational culture and institutional values expressed in their UCE policies and practice, hence, the importance of the normativity principle in UCE. This case demonstrates that founding values and other values should respond to the immediate needs of the community or stakeholders in a manner that espouses the African principle of Ubuntu-particularly in a Needs-based environment of South Africa. 


\section{Procedural principle}

Ever since their founding, universities have driven the societal transformation agenda through scientific research (Bernardo et al. 2012) and teaching and learning. They continue to be sought after as centres of knowledge generation for the common good of human kind. However, intractable problems, or problems that seem not to go away despite concerted deployment of resources, have compelled universities to seek new and innovative solutions. These unmanageable problems include, but are not limited to, crime, climate change, desertification, environmental degradation, poverty, diseases and so forth (Rittel and Webber 1973; Levin et al. 2012). These intractable problems challenge the modernity-era 'ivory tower' research that treats research participants from active communities as passive subjects. Post-modernity ushered in new sciences including sustainability, post-normal, and mode-2 sciences (Opstal and Hugé 2013) that recognises the contribution that ordinary people can make in knowledge generation for informed decision making at both policy and practice levels (Wals 2007).

Before we go any further into this topic, it is worth mentioning that we focus on the research aspect of UCE because research is one of the core businesses of any university and in certain cases it is carried our through UCE projects. We clarify this because of the fierce debates around what and what does not constitute UCE.

We then zoom into climate change as the unmanageable problem of the $21^{\text {st }}$ century (IPCC 2007; UN 2007; Levin et al. 2012) to argue the procedural principle of UCE in environmental change research. Climate change research, or impact assessment studies to be particular, acknowledges that solutions to this wicked problem will not only come from the scientists but also from community members. This is made more apparent by measurement issues in climate change, unlike in other sciences such as physics and its exact laws of gravity, climate change science is open to contestation from different schools of thoughts. Its occurrence is a scientific fact but its spatial and temporal scales remain highly contested, and this is made more contentious by climate sceptics. In recognition of this, universities would have to engage with community members solicit their indigenous or local knowledge about climate change monitoring, impacts and adaptation strategies. Research conducted within the domain of UCE seems to be the ideal platform to achieve this. The rationale for such an approach has a theoretical grounding in scientific literature, as Kloprogge and Sluijs (2006) and Wals (2007) argue that invoking the procedural principle can benefit community members in UCE endeavours. These benefits include empowerment of actors, stronger social ties between the actors, ownership of projects post university staff intervention, better decision making, and informed policy and practice and so forth. Table 1 does indicate the different levels at which 
UCE can occur whereby the university staff and community members move from mere information and consultation to collaboration and partnerships and ultimately leaving the decision making process in the hands of the community members bolstering ownership and success of the UCE initiative.

\section{Empowerment principle}

The empowerment principle is borne out of values such as equity and equality espoused in the normativity principle. The empowerment principle states that both actors in UCE endeavours should benefit from this exercise. Normally, in the context of social science research, university academics would publish research papers using primary data gathered from community members. This has been the traditional approach to university research since time immemorial. The progressive integration of UCE into scholarly research creates new opportunities for universities to regain prestige in society by realising the empowerment goals for local community development. This is imperative in an era of apathy and research fatigue perpetuated by the selfish actions of university academics. UCE offers universities the chance to reenergise, rekindle and reinvigorate the interest of community members in university activities. However, this cannot only be achieved by beneficial relationships between universities and community members only, but also by improving the perception of the former as a caring institution working towards empowerment of actors. Hence, empowerment should be an integral part of UCE principles at all universities. The procedural principle can play an important role in attaining empowerment by fostering partnerships and collaborations based on equity and equality between UCE partners. To this end, we propose a typology, in Table 1, as an important tool when planning UCE that involved community members.

\section{ANALYTIC FRAMEWORK}

In the previous sections we conceptualised community and engagement and operationalised UCE by delineating its principles in the context of scholarly research. These conceptualisation and operationalisation will now guide the process of developing a UCE typology that can be useful in guiding academics doing scholarly work in active communities. This typology is partly inspired by Bender (2008), Lazarus et al. (2008), Reed (2008) and Arnstein (1969). Later on, the authors will apply this typology to critically assess the UCE dimensions of a South African university-another key innovation in this article. 


\section{UCE typology}

In the context of UCE, both community and engagement are mutually reinforcing terms since we require active communities, meaning engaged communities, to have community engagement. Also, the term engagement itself implies that two or more parties are working alongside each other (Dempsey 2010). In the context of this article, UCE is when community members work together with academics in a back-and-forth process characterised by equal power in the decision making process. The authors have developed a UCE typology that illustrates how this utopian ideal can work in real life situations. The first column of the typology spells out the stages of participation as: non-participation, information, consultation (placation), co-decision (delegated power and partnerships), and decision (ownership, empowerment, and citizens control). The second column explains the main purpose of each participation stage as: manipulation and therapy, information, extraction, co-development (reciprocity of actions), and ownership. The third column illustrates the direction in which actions, including information, can flow each stage. Information can either flow in one direction from the academics to the community members and vice versa. Also, information can flow in both direction resulting in genuine communication between academics and community members. Last, academics can surrender their power and hand over responsibility to community members to plan and manage UCE endeavours-this is the UCE that universities strive towards. The fourth column describes the type of participation that can be achieved by each stage as: non-participation, passive participation (degree of tokenism), interactive participation (delegated power and partnerships), and active participation (self-organisation and/or citizens control). The typology comes full circle in column five which points out the nature of UCE that is achievable throughout each stage of participation as: community services (i.e. tutorial lessons for Grade 12 learners), community outreach (i.e. service learning, social programmes, student internships etc.), and community engagement (i.e. agriculture projects). Ultimately, the level of participation of community members in any UCE effort is determined by the objectives of such as an endeavour-either community services, community outreach, or community engagement.

Table 1: UCE Typology in the context of scholarly work

\begin{tabular}{|l|l|l|l|l|}
\hline $\begin{array}{l}\text { Stages of } \\
\text { participation (i.e. } \\
\text { degree of } \\
\text { participation/rungs } \\
\text { of the ladder) }\end{array}$ & $\begin{array}{l}\text { Main purpose of } \\
\text { participation (i.e. } \\
\text { objectives of } \\
\text { participation) }\end{array}$ & $\begin{array}{l}\text { Characteristics of the } \\
\text { stage (i.e. direction of } \\
\text { communication flows) }\end{array}$ & $\begin{array}{l}\text { Type of } \\
\text { participation (i.e. } \\
\text { theoretical basis/ } \\
\text { pragmatic } \\
\text { participation etc.) }\end{array}$ & $\begin{array}{l}\text { University- } \\
\text { Community } \\
\text { Engagement }\end{array}$ \\
\hline Non-participation & Manipulation & $\begin{array}{l}\text { Powerful stakeholders use } \\
\text { powerless stakeholders to } \\
\text { legitimise decision making }\end{array}$ & Non-participation & $\begin{array}{l}\text { Community } \\
\text { Services } \\
\text { (Weak UCE) }\end{array}$ \\
\cline { 2 - 3 } & Therapy & $\begin{array}{l}\text { Information/knowledge } \\
\text { flows in one direction from } \\
\text { the powerful stakeholder to } \\
\text { the powerless stakeholders }\end{array}$ & & \\
\hline
\end{tabular}




\begin{tabular}{|c|c|c|c|c|}
\hline $\begin{array}{l}\text { Stages of } \\
\text { participation (i.e. } \\
\text { degree of } \\
\text { participation/rungs } \\
\text { of the ladder) }\end{array}$ & $\begin{array}{l}\text { Main purpose of } \\
\text { participation (i.e. } \\
\text { objectives of } \\
\text { participation) }\end{array}$ & $\begin{array}{l}\text { Characteristics of the } \\
\text { stage (i.e. direction of } \\
\text { communication flows) }\end{array}$ & $\begin{array}{l}\text { Type of } \\
\text { participation (i.e. } \\
\text { theoretical basis/ } \\
\text { pragmatic } \\
\text { participation etc.) }\end{array}$ & $\begin{array}{l}\text { University- } \\
\text { Community } \\
\text { Engagement }\end{array}$ \\
\hline Information & Information & $\begin{array}{l}\text { Information/knowledge } \\
\text { flows in one direction from } \\
\text { the university community } \\
\text { members (UCMs) to the } \\
\text { external community/ } \\
\text { stakeholders (ECMs). }\end{array}$ & \multirow[t]{2}{*}{$\begin{array}{l}\text { Passive } \\
\text { participation } \\
\text { (degrees of } \\
\text { tokenism) }\end{array}$} & \multirow[t]{2}{*}{$\begin{array}{l}\text { Community } \\
\text { Outreach } \\
\text { (Weak UCE) }\end{array}$} \\
\hline $\begin{array}{l}\text { Consultation (and } \\
\text { placation) }\end{array}$ & Extraction & $\begin{array}{l}\text { Information/knowledge } \\
\text { flows in one direction from } \\
\text { the external community/ } \\
\text { stakeholders (ECMs) to the } \\
\text { university community } \\
\text { members (UCMs). }\end{array}$ & & \\
\hline $\begin{array}{l}\text { Co-decision } \\
\text { (delegated power and } \\
\text { partnerships) }\end{array}$ & Communication & $\begin{array}{l}\text { Flow of } \\
\text { information/knowledge is } \\
\text { arranged in both directions: } \\
\text { from the UCMs to the } \\
\text { ECMs and vice versa, in a } \\
\text { process of shared learning } \\
\text { (co-learning/collaborative } \\
\text { learning). }\end{array}$ & $\begin{array}{l}\text { Interactive } \\
\text { participation } \\
\text { (delegated power } \\
\text { and partnership) }\end{array}$ & \multirow[t]{2}{*}{$\begin{array}{l}\text { Community } \\
\text { Engagement } \\
\text { (Strong UCE) }\end{array}$} \\
\hline $\begin{array}{l}\text { Decision/Empowerme } \\
\text { nt (citizens control) }\end{array}$ & Ownership & $\begin{array}{l}\text { External community/ } \\
\text { stakeholders (ECMs) are } \\
\text { responsible for the UCE } \\
\text { initiative(s). }\end{array}$ & $\begin{array}{l}\text { Active participation } \\
\text { (self-organisation/ } \\
\text { citizens control) }\end{array}$ & \\
\hline
\end{tabular}

Source: researchers' own synthesis partly inspired by Bender 2008; Lazarus et al. 2008; Reed 2008; Arnstein 1969)

\section{RESULTS}

This section presents the results from the application of the UCE participation typology to UCE projects of Unisa.

Table 2: Applying UCE typology to UCE activities of UNISA

\begin{tabular}{|c|c|c|c|}
\hline $\begin{array}{l}\text { Stages of } \\
\text { participation } \\
\text { (i.e. degree of } \\
\text { participation/rungs } \\
\text { of the ladder) }\end{array}$ & $\begin{array}{l}\text { Type of } \\
\text { participation } \\
\text { (i.e. theoretical } \\
\text { basis/pragmatic } \\
\text { participation etc.) }\end{array}$ & $\begin{array}{l}\text { Weak UCE } \\
\text { or } \\
\text { Strong UCE }\end{array}$ & UCE initiatives at Unisa \\
\hline Non-participation & Non-participation & $\begin{array}{l}\text { Community } \\
\text { Services }\end{array}$ & $\begin{array}{l}\text { - Polokwane Rural Schools Development } \\
\text { - Winning Schools Project (WISP) } \\
\text { - College Student Career Day } \\
\text { - Maths, English, and Accounting Tutorials } \\
\text { - Health and Life Skills Training Project } \\
\text { - Community Asset Mapping (Camp for } \\
\text { Change) Program } \\
\text { - Unearthing a Sustainable Future } \\
\text { - Mandlethu School Project } \\
\text { - Tswelopele Skills Development Programme } \\
\text { (Human Capital Development) } \\
\text { - CEMS Going Green (inward looking) } \\
\text { - EMSSA and Enactus (Student Initiatives) } \\
\text { - Dynamics of Violence in Schools Project } \\
\text { - Vhembe Schools Project } \\
\text { - Early Childhood Development (ECD) } \\
\text { Outreach Intervention } \\
\text { - Growing ECD Teachers in Rural Areas } \\
\text { - Llima Lemfundo } \\
\text { - Science Outreach (in KZN) } \\
\text { - Analyses of Mathematics Teacher } \\
\text { Professional Development Programmes }\end{array}$ \\
\hline
\end{tabular}




\begin{tabular}{|c|c|c|c|}
\hline $\begin{array}{l}\text { Stages of } \\
\text { participation } \\
\text { (i.e. degree of } \\
\text { participation/rungs } \\
\text { of the ladder) }\end{array}$ & $\begin{array}{l}\text { Type of } \\
\text { participation } \\
\text { (i.e. theoretical } \\
\text { basis/pragmatic } \\
\text { participation etc.) }\end{array}$ & $\begin{array}{l}\text { Weak UCE } \\
\text { or } \\
\text { Strong UCE }\end{array}$ & UCE initiatives at Unisa \\
\hline Non-participation & Non-participation & $\begin{array}{l}\text { Community } \\
\text { Services }\end{array}$ & $\begin{array}{l}\text { - Learn not to Burn } \\
\text { - I-SET (Inspired Towards Science, } \\
\text { Engineering and Technology) } \\
\text { - GirlPower Project } \\
\text { - MathsEdge Project } \\
\text { - Computer Literacy in Communities (CLIC) } \\
\text { - Socially Relevant Computing } \\
\text { - Cyber Security Awareness Community } \\
\text { Engagement Project (CSACEP) } \\
\text { - Engineers Without Borders-UNISA } \\
\text { - Astronomy Outreach Programme } \\
\text { - Solar Vehicle Project } \\
\text { - ICT in Classrooms } \\
\text { - Unisa Science Exhibitor } \\
\text { - Kgautshwane Integrated Community } \\
\text { Development Programme } \\
\text { - English Language in Postgraduate Research } \\
\text { (inward looking) } \\
\text { - Mathematics and Science for Nkungumathe } \\
\text { Youth Development Project (Training in KZN) } \\
\text { - Institute for Science and Technology } \\
\text { Education Winter School Project } \\
\text { - Ukuphepha: Child Safety, Peace, and Health- } \\
\text { Community Intervention } \\
\text { - Ukuphepha: Authorship Workshop (inward } \\
\text { looking) }\end{array}$ \\
\hline $\begin{array}{l}\text { Communication/ } \\
\text { Information }\end{array}$ & & & $\begin{array}{l}\text { - Makapanstad Career Expo } \\
\text { - Community Asset Mapping (Camp for } \\
\text { Change) Program }\end{array}$ \\
\hline $\begin{array}{l}\text { Consultation (and } \\
\text { placation) }\end{array}$ & $\begin{array}{l}\text { Passive } \\
\text { participation } \\
\text { (degrees of } \\
\text { tokenism) }\end{array}$ & $\begin{array}{l}\text { Community } \\
\text { Outreach }\end{array}$ & $\begin{array}{l}\text { - Environmental and Map Literacy } \\
\text { - Entrepreneurship (E-Hub) } \\
\text { - Professional Learning in Schools } \\
\text { Management (Mpumalanga Project) } \\
\text { - ICT in Classrooms } \\
\text { - Community and Public Safety Measurement }\end{array}$ \\
\hline $\begin{array}{l}\text { Co-decsion } \\
\text { (delegated power } \\
\text { and partnerships) }\end{array}$ & $\begin{array}{l}\text { Interactive } \\
\text { participation } \\
\text { (delegated power } \\
\text { and partnership) }\end{array}$ & \multirow[t]{2}{*}{$\begin{array}{l}\text { Community } \\
\text { Engagement }\end{array}$} & \multirow{2}{*}{$\begin{array}{l}\text { - Urban Agriculture Project } \\
\text { - Lenasia Eco-schools Project } \\
\text { - Mothong African Heritage Trust project in } \\
\text { Mamelodi } \\
\text { - Entrepreneurship (SMME Summit) } \\
\text { - } 500 \text { Schools Project Lesson Study } \\
\text { - Waste to Energy for Lenasia's Thembelihle } \\
\text { ECDs } \\
\text { - Mothong Indigenous Medicine and Fruit } \\
\text { Nursery Project } \\
\text { - Photovoice Project (Ukuphepha Initiative: } \\
\text { Demonstrating African Safety) }\end{array}$} \\
\hline $\begin{array}{l}\text { Decision/Empowerm } \\
\text { ent (citizens control) }\end{array}$ & $\begin{array}{l}\text { Active participation } \\
\text { (self- } \\
\text { organisation/citizen } \\
\text { s control) }\end{array}$ & & \\
\hline
\end{tabular}

Table 2 is converted into Figure 2. It is clear that community services overwhelmingly dominate the collection of UCE projects at Unisa.

\section{DISCUSSION}

The authors discuss the results using the newly developed UCE participation typology partly inspired by Bender (2008), Lazarus et al. (2008), Reed (2008) and Arnstein (1969) that was subsequently applied to critically assess the UCE dimensions of Unisa. The discussion is 


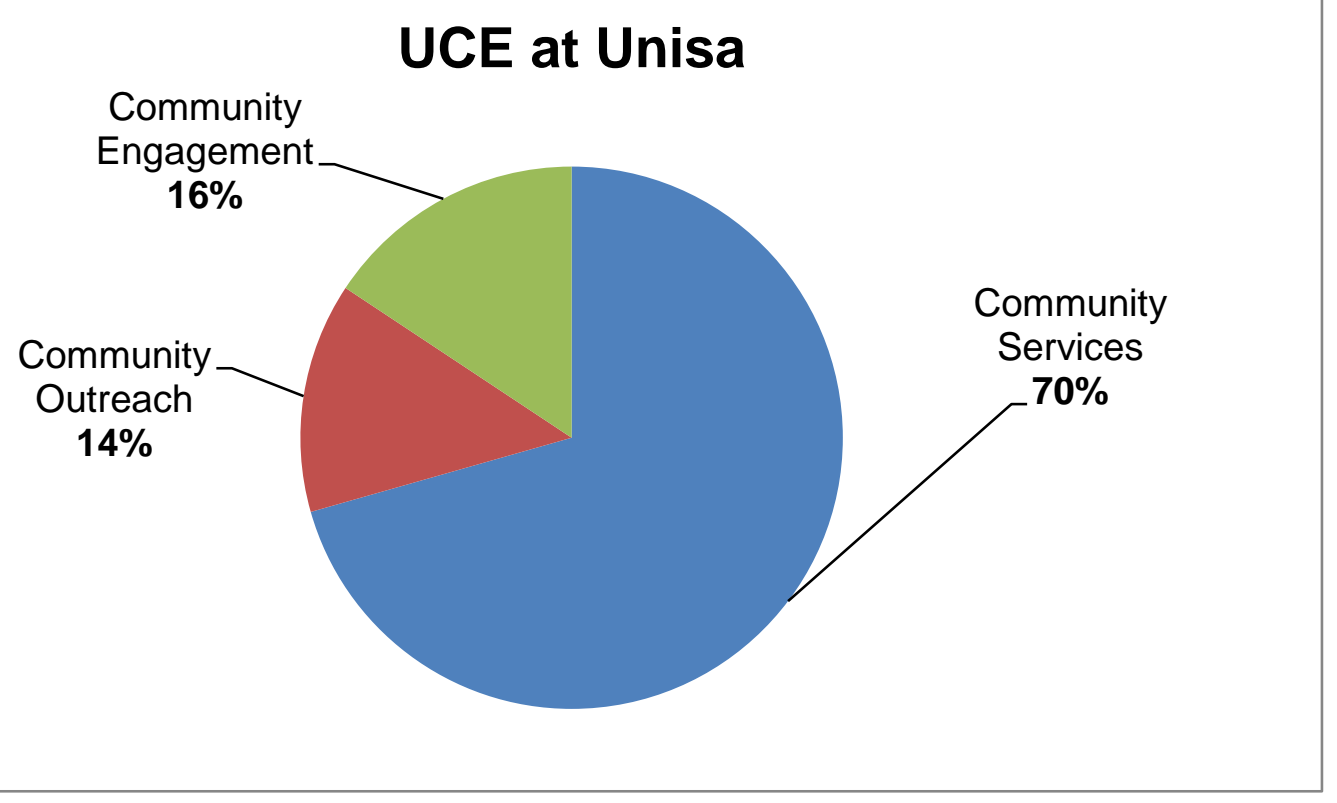

Figure 2: Percentages of UCE projects at Unisa

organised along weak and strong UCE categories. On the one hand, Weak UCE refers to community services and community outreach programmes in which community members and/or external stakeholders are passive recipients of university services and information. Knowledge flows in one direction from the 'educated' academics to the 'uneducated' community members. On rare occasions, as in the form of information and consultation, academics might ask community members to comment on their work-usually as subjects in a research study. This is classical placation whereby community members are stooges that legitimises decision made elsewhere by powerful stakeholders. On the other hand, Strong UCE starts with collaboration and partnership between academics and community members. In this arrangement, academics can delegate decision making powers to community members particularly in the context of finding politically acceptable and locally-relevant solutions to wicked problems. This delegation represents a further step towards the ownership of UCE initiatives by community members and/or external stakeholders. Citizen control is the penultimate expression of strong UCE wherein community members and/or external stakeholders are responsible for the planning and management of UCE initiatives. Informed by this background, we discuss the results from the application of the UCE participation typology as displayed in Table 2.

\section{Weak UCE}

\section{Community Services}

In the context of scholarly work, manipulation can refer to the 'ivory tower' social sciences 
research whereby community members and/or external stakeholder are subjects of academic inquiry (Cornwall 2008). Academics gain valuable primary data from these subjects and then produce conference papers, book chapters, and journal articles that propel their career progression without benefiting the research subjects-the true owners of such knowledge. In its worst form, manipulation might occur when the academic does not even provide feedback to the research subjects on his/her findings. Manipulation has been the traditional practice at universities since time immemorial and this is mainly responsible for the current apathy and fatigue towards UCE endeavours.

In Therapy, our findings reveal that initiatives akin to this practice (of therapy) dominate UCE activities at Unisa. According to Arnstein (1969), therapy refers to initiatives that aim to educate community members become in order for them to support societal transformation. Common activities undertaken by Unisa include training workshops for community members, tutorial classes to improve learners’ performance in career subjects such as Mathematics, Physical, and Accounting Sciences, career exhibitions to recruit prospective students, and awareness raising campaigns. This article argues that community services are weak UCE initiatives in which 'educated' academics 'talk at' and 'talk over' community members-the oneway flow of information in a workshop or classroom setting confirms this assertion. The absence of a feedback mechanism in this type of settings has the potential to reinforce the dominance and interest of powerful stakeholder (the usual suspects) whilst perpetuating powerlessness of community members in decision making processes and further disenfranchising them. Cooke and Kothari (2001) termed this occurrence the 'tyranny of participation' in which the (participation) setting is skewed in favour of powerful stakeholders and undermines the interests of the powerless actors.

\section{Community outreach}

Like the verb suggests, information is when 'educated' academics from universities 'talk at' and 'talk over' community members. In information, the role of community members is to 'listen to' the university 'experts'. In environmental change studies, particularly climate change, information is used to 'educate' community members about the eminent danger posed by climate change. Unlike information, consultation is a two-way process with a feedback mechanism. The two-way flow of information allows the university 'experts' to 'talk with' communities. However, in this process, decision making is reserved to the university 'experts' as they are usually the power holders and gate keepers at their institutions. Again, to use an example from climate change studies, that during consultation academics and community 
members can exchange scientific and indigenous knowledge about the occurrence of climate change. Placation is used by academics to legitimise their decision making processes but also to give credibility to their scientific inquires or research projects. Academics are aware that the involvement of community members as subjects or participants in their scholarly inquiry increases the acceptability, credibility, and transferability of their work and allows for generalisation of their findings. It also allows them to solicit and use public funds (from tax payers) by obtaining research grants (that are often tax free) from government funding agencies such as the National Research Foundation (NRF) in South Africa. In this regard, reaching out to community members, through community outreach projects, serves to benefit the university and not the community members. To its credit, Unisa, our case study area, clearly distinguishes community outreach from community engagement-this is a step in the right direction. In our analysis, only 7 projects out of 51 can be categorised as community outreach initiatives at Unisa.

\section{Strong UCE}

\section{Community engagement}

Strong UCE is characterised by collaboration and reciprocity between academics and community members. Information flows in both directions and decision-making is shared equally between the different stakeholders. This is achieved through a graduation process wherein community members move from mere partnering with academics and gradually move into decision-making roles. The ultimate objective of this graduation process is to put the management of UCE projects under the ownership of community members-through citizens' control. Only eight 8 out of 51 projects at Unisa can be regarded as truly engaging communitiesconstituting a mere 16 per cent of UCE projects at the university.

\section{Potentiality of environmentally leaning projects for realising genuine UCE}

Our analysis of UCE projects of Unisa revealed that environmentally leaning UCE projects realise strong UCE in large numbers compared to other academic fields (see Table 2). These environmentally leaning UCE projects are located in the College of Agriculture and College of Graduate studies. Perhaps this should not come as a surprise because a sizable population of South Africa still derives its livelihoods from agrarian activities including subsistence farming and livestock rearing. Certain sectors of this population is also not connected to electricity and this makes rural areas and informal settlements laboratories for technological research including in renewable energy-as in the case of the photovoltaic UCE project under the College of 
Graduate studies. These projects are important in the context of increasing socio-economic development whilst protecting the environment for the benefit of current and future generations.

Table 3: Unisa' UCE projects by College

\begin{tabular}{|c|c|c|c|}
\hline $\begin{array}{l}\text { University of } \\
\text { South Africa }\end{array}$ & Community Services & $\begin{array}{l}\text { Community } \\
\text { Outreach }\end{array}$ & $\begin{array}{l}\text { Community } \\
\text { Engagement }\end{array}$ \\
\hline $\begin{array}{l}\text { College of } \\
\text { Accounting }\end{array}$ & $\begin{array}{l}\text { Polokwane Rural Schools Development } \\
\text { Winning Schools Project (WISP) } \\
\text { College Student Career Day } \\
\text { Maths, English, and Accounting Tutorials }\end{array}$ & $\begin{array}{l}\text { Makapanstad } \\
\text { Career Expo }\end{array}$ & \\
\hline $\begin{array}{l}\text { College of } \\
\text { Agriculture and } \\
\text { Environmental } \\
\text { Sciences }\end{array}$ & $\begin{array}{l}\text { Health and Life Skills Training Project } \\
\text { Community Asset Mapping (Camp for } \\
\text { Change) Program } \\
\text { Unearthing a Sustainable Future } \\
\text { Mandlethu School Project }\end{array}$ & $\begin{array}{l}\text { Community Asset } \\
\text { Mapping (Camp for } \\
\text { Change) Program } \\
\text { Environmental and } \\
\text { Map Literacy }\end{array}$ & $\begin{array}{l}\text { Urban Agriculture Project } \\
\text { Lenasia Eco-schools } \\
\text { Project } \\
\text { Mothong African } \\
\text { Heritage Trust project in } \\
\text { Mamelodi }\end{array}$ \\
\hline $\begin{array}{l}\text { College of } \\
\text { Economic and } \\
\text { Management } \\
\text { Sciences }\end{array}$ & $\begin{array}{l}\text { Tswelopele Skills Development Programme } \\
\text { (Human Capital Development) } \\
\text { CEMS Going Green (inward looking) } \\
\text { EMSSA and Enactus (Student Initiatives) }\end{array}$ & $\begin{array}{l}\text { Entrepreneurship } \\
\text { (E-Hub) }\end{array}$ & $\begin{array}{l}\text { Entrepreneurship } \\
\text { (SMME Summit) }\end{array}$ \\
\hline $\begin{array}{l}\text { College of } \\
\text { Education }\end{array}$ & $\begin{array}{l}\text { Dynamics of Violence in Schools Project } \\
\text { Vhembe Schools Project } \\
\text { Early Childhood Development (ECD) } \\
\text { Outreach Intervention } \\
\text { Growing ECD Teachers in Rural Areas } \\
\text { Llima Lemfundo } \\
\text { Science Outreach (in KZN) } \\
\text { Analyses of Mathematics Teacher } \\
\text { Professional Development Programmes } \\
\text { Learn not to Burn }\end{array}$ & $\begin{array}{l}\text { Professional } \\
\text { Learning in } \\
\text { Schools } \\
\text { Management } \\
\text { (Mpumalanga } \\
\text { Project) }\end{array}$ & $\begin{array}{l}500 \text { Schools Project } \\
\text { Lesson Study }\end{array}$ \\
\hline $\begin{array}{l}\text { College of Human } \\
\text { Sciences }\end{array}$ & Not specified & Not specified & Not specified \\
\hline College of Law & Not specified & Not specified & Not specified \\
\hline $\begin{array}{l}\text { College of Science, } \\
\text { Engineering, and } \\
\text { Technology }\end{array}$ & $\begin{array}{l}\text { I-SET (Inspired Towards Science, } \\
\text { Engineering and Technology) } \\
\text { GirlPower Project } \\
\text { MathsEdge Project } \\
\text { Computer Literacy in Communities (CLIC) } \\
\text { Socially Relevant Computing } \\
\text { Cyber Security Awareness Community } \\
\text { Engagement Project (CSACEP) } \\
\text { Engineers Without Borders-UNISA } \\
\text { Astronomy Outreach Programme } \\
\text { Solar Vehicle Project } \\
\text { ICT in Classrooms }\end{array}$ & ICT in Classrooms & $\begin{array}{l}\text { Waste to Energy for } \\
\text { Lenasia's Thembelihle } \\
\text { ECDs }\end{array}$ \\
\hline $\begin{array}{l}\text { College of } \\
\text { Graduate Studies }\end{array}$ & $\begin{array}{l}\text { Unisa Science Exhibitor } \\
\text { Kgautshwane Integrated Community } \\
\text { Development Programme } \\
\text { English Language in Postgraduate } \\
\text { Research (inward looking) } \\
\text { Mathematics and Science for Nkungumathe } \\
\text { Youth Development Project (Training in } \\
\text { KZN) } \\
\text { Institute for Science and Technology } \\
\text { Education Winter School Project } \\
\text { Ukuphepha: Child Safety, Peace, and } \\
\text { Health-Community Intervention } \\
\text { Ukuphepha: Authorship Workshop (inward } \\
\text { looking) }\end{array}$ & $\begin{array}{l}\text { Community and } \\
\text { Public Safety } \\
\text { Measurement }\end{array}$ & $\begin{array}{l}\text { Mothong Indigenous } \\
\text { Medicine and Fruit } \\
\text { Nursery Project } \\
\text { Photovoice Project } \\
\text { (Ukuphepha Initiative: } \\
\text { Demonstrating African } \\
\text { Safety) }\end{array}$ \\
\hline $\begin{array}{l}\text { Graduate School of } \\
\text { Business } \\
\text { Leadership }\end{array}$ & Not specified & Not specified & Not specified \\
\hline $\begin{array}{l}\text { Academic } \\
\text { departments, } \\
\text { institutes, centres, } \\
\text { and bureaus }\end{array}$ & Not specified (or located in the Colleges) & $\begin{array}{l}\text { Not specified (or } \\
\text { located in the } \\
\text { Colleges) }\end{array}$ & $\begin{array}{l}\text { Not specified (or located } \\
\text { in the Colleges) }\end{array}$ \\
\hline
\end{tabular}




\section{LIMITATIONS}

It was the authors' desire to include as many South African universities in the assessment as possible. However, it proved problematic to locate the UCE sections on the website of most South African universities. In turn, this limited the assessment to Unisa which has all its UCE projects listed on its website. Future research can focus on closing this gap, but also, it would enrich the this academic field if comparisons and contrasts are drawn between UCE projects of rural versus urban-based and previous advantaged versus previously disadvantaged South African universities.

\section{CONCLUDING REMARKS}

In this article we conceptualised the highly contested terms of community and engagement. We then utilised this conceptualisation to operationalise UCE by deriving principles that can guide UCE in managing relationships with various stakeholders. These important principles were useful in the development of an analytic framework that we applied to critically assess the UCE dimensions of Unisa - a leading African university. Although our case subject, Unisa, clearly indicates on its website that it conducts community outreach and community engagement projects only. Our findings complement Unisa's position by adding another categorisation of community services. This addition to the UCE participation typology is partly inspired by Bender (2008), Lazarus et al. (2008), Reed (2008) and Arnstein (1969). The absence of this categorisation of community services, up until now, is evidence that this article makes novel contributions to the body of knowledge on UCE.

This article warned against community outreach projects that solicit the participation of community members in order to legitimise decisions made elsewhere and without their consent. This has been the traditional approach of academics applying for research grants and producing scholarly periodicals. This approach has largely been responsible for the current research fatigue experienced by community members. The article recommends that this process should be used in transition towards strong UCE-a sought of a means to an end but not the end in itself.

Strong UCE offers universities and community members a great opportunity to participate in scholarly endeavours and community works-thereby enriching both. This arrangement increases the participation dividend on both sides and also rejuvenates societal interest in scholarly endeavours. In fact, strong UCE is the Promised Land that most universities strive towards. These newly developed conceptual and analytic frameworks can bring universities somewhat nearer to this Promised Land. This article recommends that these newly developed UCE conceptual and analytic frameworks should be applied as guiding frameworks for universities across the world if we are to reach Promised Land. 


\section{ACKNOWLEDGEMENTS}

We are grateful to the anonymous reviewers whose comments greatly enriched and improved this article.

\section{REFERENCES}

Arnstein, S. 1969. 'A ladder of citizen participation'. Journal of the American Planning Association 35(4): 216-224.

Banks, S. 2003. 'What is community practice'. In Managing community practice: Principles, policies, programmes, ed. S. Banks, H. Butcher, P. Henderson and J. Robertson, 13-15. Bristol: The Polity Press.

Baxter, P. and S. Jack. 2008. Qualitative case study methodology: Study design and implementation for novice researchers. The Quarterly Report 13(4): 544-559.

Bender, G. 2008. Exploring conceptual models for community engagement at higher education institutions in South Africa. Perspectives in Education 26(1): 81-95.

Bernardo, M. A. C., J. Butcher and P. Howard. 2012. An international comparison of community engagement in higher education. International Journal of Educational Development 32(1): 187192.

Butcher, H., A. Glen, P. Henderson and J. Smith. 1993. Community and public policy. London: Pluto Press.

Butcher, H. 1993. 'Introduction: Some examples and definitions'. In Community and public policy, ed. H. Butcher et al., 3-21. London: Pluto Press.

Cornwall, A. 200). Unpacking 'Participation': Models, meanings and practices. Community Development Journal 4 (3): 269-283.

Cooke, B. and U. Kothari. 2001. Participation: The new tyranny. London: Zeb books.

Dempsey, S. E. 2010. Critiquing community engagement. Management Communication Quarterly 24(3): 359-390. doi 10.1177/0893318909352247

Etzioni, A. 1995a. New communitarianism thinking: Persons, virtues, institutions, and communities. Charlottesville, USA: University Press of Virginia.

Etzioni, A. 1995b. The spirit of community. London: Fontana

Green, L. W. and S. L. Mercer. 2001. Can public health researchers and agencies reconcile the push from funding bodies and the pull from communities? Community Participatory Research 91(12): 1926-1943.

IPCC. 2007. Climate change 2007: Impacts, adaptation and vulnerability. Contribution of Working Group II to the Fourth Assessment Report of the Intergovernmental Panel on Climate Change, ed. M. L. Parry, O. F. Canziani, J. P. Palutikof, P. J. van der Linden and C. E. Hanson. Cambridge University Press, Cambridge, UK.

IPCC. 2014. Climate Change 2014: Impacts, adaptation, and vulnerability. Part B: Regional aspects. Contribution of Working Group II to the Fifth Assessment Report of the Intergovernmental Panel on Climate Change (1199-1265). United Kingdom and New York. http://www.ipcc.ch/pdf/ assessment-report/ar5/wg2/WGIIAR5Chap22FINAL.pdf (accessed 21 March 2016).

Kitchenham, B. 2004. Procedures for performing systematic reviews. Keele University Technical Report TR/SE-0401. ISSN:1353-7776. https://scholar.google.co.za/scholar?q=procedures+for+ performing+systematic+reviews+kitchenham\&hl=en\&as_sdt=0\&as_vis $=1 \& o i=$ scholart\&sa $=X \&$ ved=0ahUKEwiHzqq7xIvMAhVHuhQKHWBlAKgQgQMIGDAA (accessed 21 March 2016).

Kitchenham, B., O. Pearl Brereton, D. Budgen, M. Turner, J. Bailey and S. Linkman. 2009. Systematic 
Literature Review in Software Engineering-A Systematic Literature Review. Information and Software Technology 51(1): 7-15. doi: 10.1016/j.infsof.2008.09.009.

Kloprogge, P. and J. P. van der Sluis. 2006. The inclusion of stakeholder knowledge and perspectives in integrated assessment of climate change. Climatic Change 75(3): 359-389. doi: 10.1007/s10584-006-0362-2.

Lazarus, J., M. Erasmus, D. Hendricks, J. Nduna and J. Slamat. 2008. Embedding community engagement in South African higher education. Education, citizenship and social justice 3(1): 5783. doi 10.1177/1746197907086719

Levin, K., B. Cashore, S. Bernstein and G. Auld. 2012. Overcoming the tragedy of super wicked problems: Constraining our future selves to Ameliorate global climate change. Policy Science 45: 123-152. doi: 10.1007/s11077-012-9151-0.

Nkoana, E. M. and M. M. Dichaba. 2016. Are we heading in the right direction? Assessing Community Engagement Dimensions of South African Higher Education Sector. South African International Conference on Education - 'Towards Excellence in Educational Practices'. African Academic Research Forum, pp. 213-224, ISBN: 978-0-620-72896-6, https://www.researchgate.net/ profile/Thobekani_Lose2/publication/308335277_A_QUALITATIVE_INQUIRY_ON_THE_C HALLENGES_FACING_INTERNATIONAL_STUDENTS_AT_INSTITUTIONS_OF_HIGHE R_LEARNING_IN_SOUTHERN_GAUTENG_SOUTH_AFRICA/links/57e12b3f08ae9834b4e 7e390.pdf\#page $=224$

Onwuegbuzie, A. J., Leech, N. L., and Collins, K. M. T. (2012). Qualitative Analysis Techniques for the Review of the Literature. The Qualitative Report 17(56): 1-28. URL Link: http://www.nova.edu/ssss/QR17/onwuegbuzie.pdf (accessed 21 March 2016).

Reed, M. S. 2008. Stakeholder participation for environmental management. A literature review. Biological Conservation 141(10): 2417-2431. doi:10.1016/j.biocon.2008.07.014.

Rittel, H. W. J. and M. M. Webber. 1973. Dilemmas in a general theory of planning. Policy Sciences 4(2): 155-169.

United Nations. 2007. Climate change: Impacts, vulnerabilities, and adaptation in developing Countries.: 1-68. Bonn: Germany. URL Link: http://unfccc.int/resources/docs/publications/ impacts.pdf (accessed 21 March 2016).

Van Opstal, M. and J. Hugé. 2013. Knowledge for sustainable development: A worldviews perspective. Environment, Development and Sustainability 15(3): 687-709.

Waas, T., J. Huge, A. Verbruggen and T. Wright. 2011. Sustainable development: A bird's eye view. Sustainability 3(12): 1637-1661. doi: 10.3390/su3101637.

Wals, A. E. J. 2007. Social learning - Towards a sustainable world: Principles, perspectives, and praxis. Netherlands: Wageningen Academic Publishers. 


\section{APPENDIX 1: List of Unisa Colleges' UCE webpage(s)}

College of Accounting Sciences. http://www.unisa.ac.za/Default.asp?Cmd=ViewContent \&ContentID=96664 (accessed 31 May 2016).

College of Agriculture and Environmental Science. http://www.unisa.ac.za/Default.asp? Cmd=ViewContent\&ContentID=28082 (accessed 31 May 2016).

College of Economic and Management Sciences (CEMS). http://www.unisa.ac.za/Default .asp?Cmd=ViewContent\&ContentID=26872 (accessed 31 May 2016).

College of Education. http://www.unisa.ac.za/Default.asp?Cmd=ViewContent\&ContentID $=27067$ (accessed 31 May 2016).

College of Human Sciences. http://www.unisa.ac.za/Default.asp?Cmd=ViewContent\& ContentID=23822 (accessed 31May 2016).

College of Law. http://www.unisa.ac.za/Default.asp?Cmd=ViewContent\&ContentID=97027 (accessed 31 May 2016).

College of Science, Engineering and Technology. http://www.unisa.ac.za/Default.asp? Cmd=ViewContent\&ContentID=22776 (accessed 31May 2016).

College of Graduate Studies. http://www.unisa.ac.za/Default.asp?Cmd=ViewContent\& ContentID=95417 (accessed 31 May 2016). 